\title{
In Turkey, factors which urge physically handicapped sporters to start badminton sport and their expectations
}

\author{
Ersin Arslan ${ }^{1 a}$, Mustafa Atl1 ${ }^{1}$, Zekiye Özkan ${ }^{1}$, and Şeyhmus Kaplan ${ }^{2}$ \\ ${ }^{1}$ School of Physical Education and Sports, Yuzuncu Yil University, 65040 Van, Turkey \\ ${ }^{2}$ Department of Sports Medicine, Medical Faculty, Yuzuncu Yil University, 65040 Van, Turkey
}

\begin{abstract}
The purpose of the study is to determine factors, which lead physically handicapped badminton players in Turkey to tend towards badminton sport, and expectations of sporters. 45 (Male: 29 Female: 16) physically handicapped sporters, who participated in Turkey Bandminton Championship for Physically Handicapped, which was arranged in Antalya on 24-26 February, 2017, from different cities, attended the study voluntarily. Developed by Sunay and his colluages [13], tendency to sports and expectation survey was used in badminton branch after expert opinions, firstly, were received and necessary regulations were made for using it in our study. In order to determine whether the difference between opinions of sporters, attending the study, according to their genders, their ages, their best sport degrees, their sport years, their parents' educational backgrounds and jobs, is important or not, one-way analysis of variance was used. To identify resource of the difference, Duncan's multiple range test was used. Kruskal Wallis $\mathrm{H}$ test was used when normality and homogeneity of variances were not provided. Value of $p$ for comparisons was taken as 0,05 . Consequently, it was determined that, in Turkey, effects of environment, friend-peer group and trainer on sporters playing at elite level as physically handicapped are high in starting badminton firstly while effects of sport complex, parents and siblings, mass media such as television and media organs on tendency to badminton are quite low. It was ascertained that liking badminton sport and delighting in earning success were effective as the reasons of physically handicappeds' playing badminton sport and their expectations were, firstly, to be chosen for national team and to be national team sporters.
\end{abstract}

Keywords: Physically Handicapped, badminton, sport

${ }^{a}$ Corresponding author: ersinarslan70@hotmail.com 


\section{Introduction}

Sport activities have become important for the handicapped recently. In our country, an important increase was seen in tendencies of individuals with special necessity to sport thanks to growth of sensitiveness towards the handicapped at government policy and provided facilities.

Physically disability is identified as any physical situation which includes obstacles coming to light from birth or as result of a disease and affects child's educational performance [9]. Education chance of handicapped individual can be increased by removing environmental obstacles and increasing capableness and rehabilitating in the way that he/she can optimise his/her present potential. The physically handicapped people, who have no difference from other children in terms of learning capacity, have been dispossessed of education chances most often due to transportation problems and architectural obstacles at home and schools and their coalescing with society has been precluded. Tending of the physically handicapped people to sport is important in terms of life quality like the individuals who make normal progress [12].

Sport is asserted as competitive, solidarist and cultural notion improving socializer soul and physics and abilities, which individual obtains while he/she turns nature environment into humane environment, and a notion that individual does by making it profession in such a way that the sport will take his/her al lor leisure time individually or with group and with tool or without tool under certain rules [2]. Badminton sport has begun to take place among the sport branches that physically handicapped people interested in.

Among the reasons of being preferred of badminton, its elegant feature and its not requiring special area or track is effective. It is played out of town, at picnic and street and in water and even on ice. Because of this feature, badminton play meets societies' health and need for movement. And also, in terms of charactertistic of the play, badminton sport maintains its characteristic of being one of kind of the activities developing physical capacity ideally and generally as aerob. This feature of badminton brings it in ability in which people of all ages can perform an application according to their own performance [20]. Tending to sport begins at young ages. In physically handicapped people, tending to sport is realised in the fields that individual feels he/she is qualified.

Among the factors which influence a young competitor's attending sport, encouragement and incentive factors, proving himself/herself, aggression, selectness, independance, power, stres and success are influential [19]. Sport has an important role in personality development [21].

\section{Method}

\subsection{The purpose of the study}

The purpose of the study is to determine factors, which lead physically handicapped badminton players in Turkey to tend towards badminton sport, and expectations of sporters.

\subsection{Problem of the study}

Problem of the study is to research whether factors, which lead physically handicapped badminton players in Turkey to tend towards badminton sport, and expectations of sporers show difference according to demographic characteristics or not. 


\subsection{Data collection tool}

The survey, which was used in the study (Tendig to sport and expectations) was developed by Sunay and his colluages and was applied to other branches. Validity and dependability of the survey was accepted [13]. Survey was used in badminton branch by receiving expert opinions and making necessary regulations for using it in our study. In the first part of the survey, there are personal informations of sporters who attended the study, and then in the second part of the survey, there are factors which urge to badminton sport and reasons for playing, lastly, in the third part of the survey, there are opinions about expectations from badminton sport.

\subsection{Participants}

45 (Male: 29 Female: 16) physically handicapped sporters, who participated in Turkey Bandminton Championship for Physically Handicapped, which was arranged in Antalya on 24-26 February, 2017, from different cities, attended the study voluntarily.

\subsection{Statistical analysis}

Data obtained from the survey were clarified and commented with frequencies and percentages. Moreover, in order to determine whether the difference between criterions related to genders, ages, best sport degrees, sport years, educational backgrounds and jobs of the parents of sporters attending the study is important or not, one-way analysis of variance was done. To identify resource of the difference, Duncan's multiple range test was used. Kruskal Wallis $\mathrm{H}$ test was used when normality and homogeneity of variances were not provided. Value of $\mathrm{p}$ for comparisons was taken as 0,05 . and significance level was taken as $\% 5$ for comparisons.

\section{Findings and comment}

In this study, determination of the factors which urge male and female (Male: 29 Female: 16) physically handicapped sporters, who participated in Turkey Bandminton Championship for Physically Handicapped, which was arranged in Antalya on 24-26 February, 2017, from different cities, to badminton sport and of expectations was aimed. Many factors are effective in tending of individuals to sport. In the factors which determine the tending, sufficiency of person, family factor, environmental factors, media, social environment, economic factors are effective.

Table 1. Singificance Levels of the factors which urge physically handicapped people to badminton sport

\begin{tabular}{|c|c|c|c|}
\hline $\begin{array}{c}\text { the Factors which urge physically handicapped people } \\
\text { to badminton sport }\end{array}$ & $\overline{\mathbf{X}}$ & $\mathbf{S S}$ & $\begin{array}{c}\text { Significance } \\
\text { Level }\end{array}$ \\
\hline 1. Effect of parents and sibling in tending to sport & 5,7333 & 1,87568 & 7 \\
\hline $\begin{array}{c}\text { 2. Effect of environment in which you live in tending to } \\
\text { sport }\end{array}$ & 3,5111 & 2,41795 & 3 \\
\hline 3. Effect of friend and peer group in tending to sport & 3,2444 & 1,72093 & 2 \\
\hline 4. Effect of physical education teacher in tending to sport & 4,9111 & 2,15134 & 5 \\
\hline 5. Effect of media organs in tending to sport & 4,6889 & 2,05407 & 4 \\
\hline 6. Effect of television channels in tending to sport & 5,1111 & 1,99114 & 6 \\
\hline $\begin{array}{c}\text { 7. Effect of school complex and materials in tending to } \\
\text { sport }\end{array}$ & 6,1111 & 1,84911 & 8 \\
\hline $\begin{array}{c}\text { 8.Effect of the trainer in close environment in tending to } \\
\text { sport }\end{array}$ & 2,6889 & 1,90481 & 1 \\
\hline
\end{tabular}


When examining singificance levels of the factors which urge physically handicapped people to badminton sport, it was seen that in the first level, there is fffect of the trainer in close environment in tending to sport, then in the second level, there is effect of friend and peer group in tending to sport, lastly, in the third level, there is effect of environment in which you live in tending to sport

Table 2. Significance Levels of the reasons of physically handicapped people's playing badminton

\begin{tabular}{|c|c|c|c|}
\hline Reason For Playing Badminton & $\overline{\mathbf{X}}$ & SS & $\begin{array}{c}\text { Signifi } \\
\text { cance } \\
\text { Level }\end{array}$ \\
\hline 9. To increase revenue & 6,4667 & 3,04213 & 8 \\
\hline 10. To like badminton sport & 2,1111 & 1,96818 & 1 \\
\hline 11. To be aware of positive contributions of sport & 5,8444 & 7,93140 & 7 \\
\hline 12. To attend a friend group easily & 7,4318 & 1,82231 & 9 \\
\hline 13. To value leisure time by doing sport & 5,8444 & 1,94183 & 6 \\
\hline 14. To be healthy by playing badminton & 4,4444 & 2,11655 & 3 \\
\hline 15. To be known, loved and respected by friends as a sporter & 5,2667 & 1,83897 & 5 \\
\hline 16. To delight in earning success & 3,7556 & 2,101147 & 2 \\
\hline 17.To move with friends in a team spirit & 4,9333 & 2,28035 & 4 \\
\hline
\end{tabular}

When examining significance levels of the reasons of physically handicapped people's playing badminton, it has been seen that in the first level, there is to love badminton, and then in the second level, there is to delight in earning success, lastly, in the third level, there is to be healty by playing badminton.

Table 3. Expectations of physically handicapped sporters from badminton sport

\begin{tabular}{|c|c|c|c|}
\hline Expectations from Badminton Sport & $\overline{\mathbf{X}}$ & SS & $\begin{array}{c}\text { Signific } \\
\text { ance } \\
\text { Level }\end{array}$ \\
\hline 18. To be and keep healthy & 4,4667 & 3,00454 & 2 \\
\hline $\begin{array}{c}\text { 19.To have a good physical appearence } \\
\text { popular person doing sport }\end{array}$ & 6,4000 & 2,799935 & 8 \\
\hline 20. To maintain relationship with his/her environment as a \\
21. To be a good sporter and to earn living through sports & 7,5111 & 2,31224 & 10 \\
\hline 22. To be trained for sport at university level in the future & 4,8182 & 2,65253 & 3 \\
\hline 23. To be trainer & 5,0433 & 2,35874 & 5 \\
\hline 24. To be referee & 6,6889 & 2,37368 & 4 \\
\hline 25. To be physical education teacher & 6,2444 & 2,595806 & 9 \\
\hline 26. To obtain financial potential & 5,7333 & 2,79935 & 7 \\
\hline 27. To be chosen for national team and to be national sporter & 2,3556 & 1,92065 & 1 \\
\hline
\end{tabular}

When examining significance levels of expectations of physically handicapped sporters from badminton sport, it has been seen that in the first level, there is expectation for being chosen for national team and being national sporter, and then in the second level, there is expectation for being and keeping healthy, lastly, in the third level, there is expectation for being a good sporter and earning living through sport. 
Table 4. Variance analysis of factors urging to badminton sport according to sports year of the physically handicapped

\begin{tabular}{|c|c|c|c|c|c|c|}
\hline $\begin{array}{c}\text { Factors Urging to Badminton } \\
\text { Sport }\end{array}$ & $\begin{array}{l}\text { Sport } \\
\text { Year }\end{array}$ & $\mathbf{N}$ & $\overline{\mathbf{X}}$ & SS & $\mathbf{F}$ & Sig. \\
\hline \multirow{3}{*}{$\begin{array}{c}\text { Press Factor (media organs, television } \\
\text { channels) }\end{array}$} & $<5$ year & 20 & 11,5500 & 3,41012 & \multirow{3}{*}{4,786} & \multirow{3}{*}{0,013} \\
\hline & 5-10 year & 13 & 8,0769 & 3,72965 & & \\
\hline & $\geq 10$ year & 12 & 8,7500 & 3,13702 & & \\
\hline \multirow{3}{*}{$\begin{array}{c}\text { Environmental Factors (environment in } \\
\text { which he/she live,friends, } \\
\text { parents,siblings) }\end{array}$} & $<5$ year & 20 & 12,5500 & 2,87411 & \multirow{3}{*}{0,345} & \multirow{3}{*}{0,710} \\
\hline & 5-10 year & 13 & 13,0000 & 4,06202 & & \\
\hline & $\geq 10$ year & 12 & 11,8333 & 3,92737 & & \\
\hline \multirow{3}{*}{$\begin{array}{l}\text { Other Factors(Physical education teacher, } \\
\text { school sport complex and matearials, } \\
\text { trainer) }\end{array}$} & $<5$ year & 20 & 11,9000 & 3,49285 & \multirow{3}{*}{5,348} & \multirow{3}{*}{0,009} \\
\hline & 5-10 year & 13 & 14,9231 & 2,92864 & & \\
\hline & $\geq 10$ year & 12 & 15,4167 & 3,50216 & & \\
\hline
\end{tabular}

A significant difference of press factor in urgin to badminton sport according to sporters' sports year was seen $(\mathrm{p}<0.05)$. A significan difference of environmental factors in urginto badminton sport according to sporters' sports year was not seen $(\mathrm{p}>0.05)$.

Table 5. Results of Kruskal Wallis $H$ test of factors urging to badminton sport according to educational backgrounds of sporters' mother

\begin{tabular}{|c|c|c|c|c|c|}
\hline $\begin{array}{l}\text { Factors Urging to Badminton } \\
\text { Sport }\end{array}$ & Education & $\mathbf{N}$ & $\overline{\mathrm{x}}$ & SS & Sig. \\
\hline \multirow{4}{*}{$\begin{array}{l}\text { Press Factor (media organs, } \\
\text { television channels) }\end{array}$} & Illiterate & 10 & 7.4000 & 3.77712 & \multirow{4}{*}{$\mathrm{o.038}^{*}$} \\
\hline & Literate & 9 & 8.8889 & 2.84800 & \\
\hline & Primary & 15 & 11.4667 & 3.97971 & \\
\hline & High School & 11 & 10.4545 & 2.87623 & \\
\hline \multirow{4}{*}{$\begin{array}{l}\text { Environmental Factors } \\
\text { (environment in which he/she } \\
\text { live,friends, parents,siblings) }\end{array}$} & Illiterate & 10 & 12.6000 & 3.83551 & \multirow{4}{*}{0.937} \\
\hline & Literate & 9 & 12.4444 & 2.60342 & \\
\hline & Primary & 15 & 12.4667 & 3.60291 & \\
\hline & High School & 11 & 12.4545 & 4.05866 & \\
\hline \multirow{4}{*}{$\begin{array}{l}\text { Other Factors(Physical } \\
\text { education teacher, school sport } \\
\text { complex and matearials, trainer) }\end{array}$} & Illiterate & 10 & 16.0000 & 3.23179 & \multirow{4}{*}{$0.035^{*}$} \\
\hline & Literate & 9 & 14.6667 & 2.00000 & \\
\hline & Primary & 15 & 12.0667 & 3.84460 & \\
\hline & High School & 11 & 13.0909 & 3.88470 & \\
\hline
\end{tabular}

A significant differecen was found among education level of mother in terms of pres factor $(\mathrm{p}<0.05)$. Difference was seen in primary and illiterate according to multiple range test which was done to determine resource of the differance (chi square=7.19). A significant differecen was observed among education level of mother in terms of school sport complex and materials and trainer factors $(\mathrm{p}<0.05)$. Similarly, difference was found in primary and illiterate according to results of multiple range test which was done to determine resource of the difference (chi square $=8.12$ ). A significant difference among fathers' education levels was not found in terms of press, environment and other factors. 
Table 6. Variance analysis of the reasons of physically handicapped people's playing badminton according to sports degree of the physically handicapped

\begin{tabular}{|c|c|c|c|c|c|c|}
\hline Reasons for playing badminton & $\begin{array}{c}\text { Sport } \\
\text { Degree }\end{array}$ & $\mathbf{N}$ & $\bar{x}$ & SS & $\mathbf{F}$ & Sig. \\
\hline \multirow{3}{*}{$\begin{array}{l}\text { To move with friends in a team } \\
\text { spirit } \\
\text { To be known, loved and respected } \\
\text { by friends as a sporter } \\
\text { To attend a friend group easily }\end{array}$} & Turkey & $\begin{array}{l}3 \\
1\end{array}$ & $\begin{array}{c}18.064 \\
5\end{array}$ & 3.82043 & \multirow{3}{*}{3.433} & \multirow{3}{*}{$\underset{*}{0.042}$} \\
\hline & Wold & 8 & $\begin{array}{c}19.000 \\
0\end{array}$ & 4.34248 & & \\
\hline & Province & 6 & $\begin{array}{c}13.600 \\
0\end{array}$ & 3.045981 & & \\
\hline \multirow{3}{*}{$\begin{array}{c}\text { To increase revenue } \\
\text { To like badminton sport } \\
\text { To be aware of positive } \\
\text { contributions of sport } \\
\text { To value leisure time by doing sport } \\
\text {. To be healthy by playing } \\
\text { badminton To delight in earning } \\
\text { success }\end{array}$} & Turkey & $\begin{array}{l}3 \\
1\end{array}$ & $\begin{array}{c}26.838 \\
7\end{array}$ & 3.55993 & \multirow{3}{*}{7.004} & \multirow{3}{*}{$\underset{*}{0.002}$} \\
\hline & World & 8 & $\begin{array}{c}26.000 \\
0\end{array}$ & 4.34248 & & \\
\hline & Province & 6 & $\begin{array}{c}40.166 \\
7\end{array}$ & 21.64640 & & \\
\hline
\end{tabular}

A significant difference between variables, forming a circle of friends and providing moral and material benefits, and sports degree was determined $(\mathrm{p}<0.05)$.

\section{Discussion and conclusion}

In this study, determination of the factors which urge male and female (Male: 29 Female: 16) physically handicapped sporters, who participated in Turkey Bandminton Championship for Physically Handicapped, which was arranged in Antalya on 24-26 February, 2017, from different cities, to badminton sport and of expectations was aimed. Many factors are effective in tending of individuals to sport. In the factors which determine the tending, sufficiency of person, family factor, environmental factors, media, social environment, economic factors are effective.

In our study, when examining divisions of views related to factors which urge the physically handicapped sporters to badminton sport, it was seen that the trainer in close environment was effective in the first level. Alibaz and his colluages determined in their study that the tranier was effective highly in starting of taekwondo, karate and kick-box sporters to this sport, and it supports our study. But in the studies which were done with different sample groups in literature, the most effective factor in urging to sport was mother, it is seen that the results contrary to our study revealed [4,5,6,8,13,16,18,22]. It is thought that this is because parents, who have physically handicapped individual, behave extremely protector and do not have essential confidence and information for urging their child to sport.

In our study, it was seen that effects of friend, peer group and environment in which he/she lives in tending to sport are important. While Salman and Sunay [18] has found effects of friend and environment high as result of the study they did, it is claimed that while effect of the trainer in close environment is at second rank in the study Sunay and Saraçoğlu [13] did, friend and peer group is third order of importance. And also, in our study, it was determined that effects of parents, sibling and pyscial education teachers in urging to badminton sport were at low level. Results of the study Bavlı [17] and Akçay [15] did supports our study.

In our study, it was seen that effect of media organs in starting to sport was not much. Result of the study which Salman and Sunay [18], Bayraktar and Sunay [4], Sunay and Saracoglu [13] did with different sample groups supports our study. It is known that in 
mass media, badminton and other sports branches, except for futbol and a few sports branches, are not taken on interests adequately. Inadequancies are seen in social lifes of the physically handicapped compared to individuals showing normal development. That's why, it is thought that press factor can provide important contributions for tending of the physically handicapped to sport.

As a result of our study, physical education teacher was not seen to be much effective in starting of sporters to badminton sport. Based on this result, it was concluded that introduction of the physically handicapped with badminton sport did not occur during school education. However, Bayraktar and Sunay [4] claim that in the first level, physical education teacher has effect in urging to sport in volleyball branch at elite level, and Şimşek and Gokdemir [10] suggest that in the first level in tending of high school students to athleticism, physical education teacher has effect in urging to sport. Based on these results, it can be said that in different sports branches, effects of physical education teacher are different in urgint to sport and this is due to information and experiences of physical education teacher.

In our study, when examining divisions of the reasons for playing badminton sport, it was seen that to love badminton sport was so effective. The studies in literature also supports our study $[1,4,5,18,22]$. It can be said that the sport done by loving brings continuity and success with itself. It was observed that to delight in earning success was quite effective in being interest in badminton sport. That every success is a big resource of motivation for sporters and is known by society reinforces competitor identity of sporters. Furthermore, in our study, it was seen that effect of being healthy by playing badminton sport in being interested in badminton sport also was so effective. And it is supported with the study Bayraktar and Sunay [4] did. Sporters' being healthy by doing sport, their keeping fit, their having a durable body and their making philosophy of lifelong sport a unchangable activity of life increase life quality of physically handicapped individuals.

In our study, when examining divisions of opinions related to expectations of sporters from badminton sport, it was seen that being a national team player had important role and most of sporters wanted to be a national team player and represent the country by wearing national team uniform. This result is supported with the studies done in different branches $[14,18]$.

In our study, a significant difference between press( media organs, television channels) and other factors( physical education teacher, school sport complex and materials, trainer) in urging sporters to badminton sport was seen $(p<0.05)$. And also, significant difference between press and other factors and mother education level was found $(p<0.05)$.

Kılınç and Kumartaşli [11] claim that education level of family is influential in handicapped individuals' doing sport. In the study Kotan and his colluages [7] did with primary school children, it is suggested that education level of family has effect on doing sport of child. In the study Yucel and his colluages [13] did, it is stated that some factors such as place, parents education, level of income, diet habits etc. are effective in preferring sports branches. These studies support our study. All of literature studies that we examined includes sporters showing normal development. However, because our study includes physically handicapped sporters, inadequancies of the studies related to this field limited our comparison chance.

As a result of our study, it was seen that effects of the trainer in close environment, friend, peer group and environment where he/she lives in tending to sport were important in urging physically handicapped in Turkey to badminton sport. effects of parents, siblings and physical education teacher in urging to badminton sport was seen to be at low level. When examinin reasons for playing the sport, to like badminton sport, to delight in earning success, to healthy by playing badminton sport were seen to be important. When examining expectations from badminton sport, in the first degree, there were to be chosen for national 
team, to be a national sporter, to be healthy, to keep healthy, to be a good sporter and to earn living through sports. It is thought that raising awareness of society will influnce sports life of individuals with special necessity in a positive way and families having individual with special necessity will be effective in urging to sport.

\section{References}

1. A. Alibaz, N. Gündüz, M. Şentunay, Spormetre Physical Education and Sport Sciences Journal, 4, 3 (2006)

2. A. N. İnal, Phscical Education and Sport Science. (Nobel Publishing) (2003).

3. A. S. Yücel, B. Kılıç, M. Korkmaz, K. Göral, International Refereed, Academic, Sport, Health and Medicine Sciences Journal, 5, 14 (2015).

4. B. Bayraktar, H. Sunay, Spormetre Physical Education and Sport Sciences Journal, 5, 2 (2007)

5. B. Ölçücü, G. Erdil, Ö. Bostancı, A. Canikli, A. Aybek, Journal of Sports and Performance Researches, 3, 2 (2012)

6. B. Ölçüçü, Ş. Özen, M. Altınkök, International Turkish Sciences Journal, October (2014)

7. C. Kotan, G. Hergüner, C. Yaman, Nigde University Journal of Physical Education and Sport Sciences ,3, 1 (2009)

8. D. K. Arpa, Master's Thesis at Graduate School of Health Sciences, Haliç University, (2014)

9. D. S. Özer, Engelliler için beden eğitimi ve spor. (Nobel, 4th press) (2013)

10. D. Şimşek, K. Gökdemir, Spormetre Physical Education and Sport Sciences Journal, 4, 3 (2006)

11. F. Kılınç, M. Kumartaşl1, 1st International Congress on Physical Education and Sport at Physically Handicapped, (2011)

12. H. Kayihan. Fiziksel Engellilerde rehabilitasyon eğitim ve toplumsal katılım. N. Baykoç Dönmez (Ed.), Özel Gereksinimli Çocuklar ve Özel Eğitim içinde. (p. 244 Eğiten Kitap) (2011)

13. H. Sunay, A. S. Saraçoğlu, Spormetre Physical Education and Sport Sciences Journal, 1, 1 (2003)

14. M. Binboga, İ. Kılıç, K. Gökdemir, Journal of Sport and Performance Researches, 4, 2 (2013)

15. N. Ş. Akca, Graduate School of Health Sciences (2012)

16. O. Özbek, E. Şanli, Nigde University Journal of Physical Education and Sport Sciences, 5, 3 (2011)

17. Ö. Bavl1, Nigde University Journal of Physical Education and Sport Sciences, 3, 3 (2009)

18. Ö. Salman, H. Sunay, Spormetre Physical Education and Sport Sciences Journal, 10, 1 (2012)

19. R. Kale, E. Erșan, Beden eğitimi ve spor bilimlerine giriș. (Printing of Karadeniz Technical University). (2003)

20. R.C. Memedov, R. Kale, Uçan Tüytop Badminton, (1994)

21. Ü. Tazegül, 2nt International Congress on Physical Education and Sport at Physically Handicapped, (2014)

22. Y. Yıldırım, H. Sunay, Spormetre Physical Education and Sport Sciences Journal, 7, 3 (2009) 